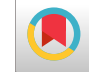

\title{
Association Between MspI Polymorphisms of the Apolipoprotein A-I Gene and Hyperlipidemia in an Iranian Population
} \author{
Abbas Pakdel,,$^{1,2}$ Mohammad Reza Akbari Eidgahi, ${ }^{3}$ and Ahmad R. Bandegi ${ }^{1,2, *}$ \\ ${ }^{1}$ Nervous System Stem Cells Research Center, Semnan University of Medical Sciences, Semnan, IR Iran \\ ${ }^{2}$ Department of Biochemistry, Faculty of Medicine, Semnan University of Medical Sciences, Semnan, IR Iran \\ ${ }^{3}$ Biotechnology Research Center, Semnan University of Medical Sciences, Semnan, IR Iran \\ "Corresponding author: Ahmad R. Bandegi, Nervous System Stem Cells Research Center, Semnan University of Medical Sciences, Semnan, IR Iran. Tel: +98-2313354170; Fax: \\ +98-2313354161, E-mail: arbandegi@yahoo.ca
}

Received 2017 August 23; Revised 2017 November 20; Accepted 2017 November 28.

\begin{abstract}
Background: One of the most important metabolic disorders is hyperlipidemia. ApoAI protein plays an important role in lipoprotein metabolism. In this study, the association between MspI polymorphisms in the promoter (G-75A) and first intron (C83T) of the apoAI gene and hyperlipidemia was investigated in Semnan, Iran.

Methods: A total of 151 unrelated subjects were divided into two groups: the hyperlipidemic $(\mathrm{N}=75)$ and control $(\mathrm{N}=76)$ groups. Genotyping was carried out by polymerase chain reaction-restriction fragment length polymorphism (PCR-RFLP).

Results: In the hyperlipidemic group, the frequency of the (+-) variant of the MspI (C83T) locus was higher than that in the control group $(\mathrm{P}<0.05)$. Significant differences were found in serum HDL-C and apoAI levels between different genotypes of MspI (C83T) $(\mathrm{P}<0.001$ and $\mathrm{P}=0.02$, respectively). In the hyperlipidemic group, the odds ratios for the (+-) and (-) genotypes of the MspI (C83T) locus in comparison to that for the $(++)$ genotype were $0.26(\mathrm{P}=0.023)$ and $3.62(\mathrm{P}=0.254)$, respectively. The allelic frequency at the (G-75A) locus was not significantly different in the hyperlipidemic and control groups $(P=0.36)$. The serum levels of lipid and lipoprotein were not significantly different for all genotypes of MspI (G-75A). The AA/++ and GG/- haplotypes had the lowest and highest apoB/apoAI ratios, respectively (0.73 \pm 0.03 vs. 1.9$)$.

Conclusions: The presence of $(+)$ and A alleles in the apoAI (C83T) and (G-75A) haplotypes in the Semnan population may be protective against cardiovascular disease.
\end{abstract}

Keywords: Apolipoproteins B, Apolipoprotein AI, Restriction Fragment Length Polymorphism, Hyperlipidemi

\section{Background}

Hyperlipidemia is characterized by abnormally elevated levels of lipids in the blood and is known to be a risk factor for different diseases, such as coronary heart disease, cancer, fatty liver, and so on (1-4) Genetic and environmental factors play an important role in different forms of dyslipidemia (5). Several studies in Iran have shown a high prevalence of dyslipidemia in different age groups $(6,7)$. Lipid-associated single nucleotide polymorphism (SNP) of several candidate genes has been previously described (5, 8-10). ApoB- and apoAI-containing lipoproteins are potentially atherogenic and anti-atherogenic, respectively. The ratio between apoB/apoAI could show a balance between atherogenic and anti-atherogenic lipoproteins $(11,12)$. ApoAI, the main apolipoprotein of HDL, is a candidate gene for dyslipidemia pathophysiology. ApoAI gene polymorphisms can change the expression of apoAI and the blood level of the apoAI protein (13-15); there- fore, many researchers are interested in the assessment of apoAI SNPs. ApoAI gene is a part of the apolipoprotein apoAI/CIII/AIV gene cluster located on chromosome 11 q23 (16). The apoAI gene SNPs were evaluated under different conditions, such as obesity $(17,18)$, myocardial infarction (19-22), diabetes, and metabolic syndrome (23, 24). (G-75A) and (C83T), the most important polymorphic sites in the apoAI gene, are located in the upstream regulatory region and the first intron of apoAI gene, respectively (14). The (G75A) and (C83T) polymorphic sites were evaluated in association with serum lipid and lipoproteins in the different study populations (13-15, 25).

\section{Objectives}

ApoAI gene polymorphism studies have shown conflicting results in different hyperlipidemic populations (1315, 18, 20, 24, 26-29). A study has been performed in Tehran populations. Since the Apo A1 gene polymorphism has not 
been performed in the Semnan population, this study was designed. According to the high prevalence of hyperlipidemia in Iran, especially in middle-aged people (6), serum lipid levels and the apo B/apoAI ratio were evaluated in association with (G-75A) and C(C83T)T polymorphism in subjects with hyperlipidemia in Semnan.

\section{Methods}

\subsection{Study Subjects}

The protocol of study was approved by the Ethical Committee of Semnan University of Medical Sciences. A total of 151 unrelated subjects was serially recruited for the study by the physicians from the diabetes research center (Semnan, Iran). An informed written consent was obtained from each subject for participation in the study prior to sampling. Patients with hypothyroidism, diabetes mellitus, hypertension, alcoholism, renal failure, and hepatic disease and patients receiving drugs affecting lipid profile or lipid-lowering drugs were excluded. Subjects with a TG concentration of $>150 \mathrm{mg} / \mathrm{dl}$ and total cholesterol of $>200 \mathrm{mg} / \mathrm{dl}$ were included in the hyperlipidemic group. The healthy control was defined as a normal, healthy group with plasma concentrations of TG of $<150$ and TC of $<200$ $\mathrm{mg} / \mathrm{dl}$. Both patients and controls had a Semnanian native origin and possibly had a similar genetic background. Table 1 shows the characteristics of the study population.

\subsection{DNA Isolation and Genotyping}

Genomic DNA was isolated from whole blood cells anticoagulated with EDTA using a "salting-out" procedure (26). Polymerase chain reaction (PCR) was used to amplify the fragment of $433 \mathrm{bp}$ at the 5' end of the apoAI gene. To amplify the 5' end of the apoAI gene containing the polymorphic MspI sites, the following primer sequences were used: forward primer 5'-AGGGACAGAGCTGATCCTTGAACTCTTAAG-3, and reverse primer was 5'TTAGGGGACACCTACCCGTCAGGAAGAGCA-3' $(5,12)$. PCR was carried out in a $25 \mu \mathrm{l}$ final volume containing $10 \mathrm{pmol}$ of each primer, 50 ng genomic DNA, $2.5 \mu \mathrm{l}$ of $10 \times$ reaction buffer, $2 \mathrm{mM} \mathrm{MgCl} 2,0.1 \mathrm{mM}$ dNTP, and 1 unit of Taq DNA polymerase. PCR conditions involved denaturation for $4 \mathrm{~min}$ at $94{ }^{\circ} \mathrm{C}$ and 33 cycles of denaturation for 1 min at $94{ }^{\circ} \mathrm{C}$, annealing for $1 \mathrm{~min}$ at $64{ }^{\circ} \mathrm{C}$ and extension for 2 min at $72^{\circ} \mathrm{C}$. The last amplification step was prolonged to $5 \mathrm{~min}$. PCR products were run on 1.5\% agarose gel and photographed directly under a UV transilluminator (Figure 1). An aliquot of $10 \mu \mathrm{l}$ of the PCR product was digested at $37^{\circ} \mathrm{C}$ for 4 hours with 2.5 units of MspI restriction enzyme and specific restriction buffer in a final volume of $25 \mu \mathrm{l}$. Following digestion, the samples were run on $12 \%$ polyacrylamide gels in parallel with a 50 bp DNA ladder and then stained using silver staining procedure (Figure 2 ).

\subsection{Plasma Lipids and Apolipoproteins Analysis}

The total cholesterol and triglycerides were determined enzymatically on an automated analyzer. HDL-c, LDL-c, apoAI, and apoB were measured using an automated immunoturbidimetric method.

\subsection{Statistical Analysis}

Statistical analysis was performed using SPSS statistical software version 16 . Results were reported as a mean \pm standard error of the mean (mean \pm SEM). A p-value less than $0.05(\mathrm{P}<0.05)$ was considered statistically significant. Allele frequencies were determined by the allelecounting method. Genotype frequency was calculated by dividing the number in each genotype by the total number of individuals genotyped. Hardy-Weinberg equilibrium was tested using the $\chi^{2}$ test. The clinical characteristics of the continuous variables of two groups were compared by unpaired Students t-test. Analysis of variance followed by Tukey's test (in a case of significant effects) was used to estimate the effects of the different genotypes on lipid parameters.

\section{Results}

4.1. Demographic and Biochemical Characteristics of the Study Population

Table 1 presents the demographic and biochemical characteristics of the study population. The study population comprises a sample of $45.7 \%$ men and $54.3 \%$ women. The age range was between 17 and 65 years.

Figure 1. Gel Electrophoresis (1.5\% Agarose Gel) of 433 bp PCR Product of the ApoAl Gene.

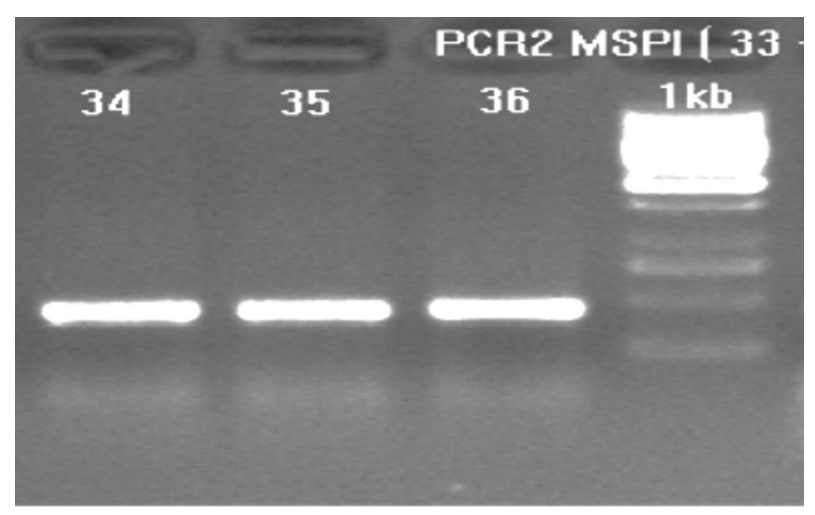

Lanes 1 to 3 are PCR products of three samples and M is $1 \mathrm{~Kb}$ DNA size Marker. 
Table 1. Demographic and Biochemical Characteristics of the Study Population

\begin{tabular}{|c|c|c|c|}
\hline Parameter & Controln $=75$ & Patients $n=76$ & Comparison $\mathrm{P}$ \\
\hline Age (year) & $45.3 \pm 1.4$ & $46.1 \pm 1.2$ & $\mathrm{NS}^{\mathrm{a}}$ \\
\hline Men/Women & $35 / 40$ & $34 / 42$ & NS \\
\hline BMI $^{\mathbf{b}}$ & $24.7 \pm 0.4$ & $26.9 \pm 0.4$ & $\mathrm{P}<0.001$ \\
\hline Total cholesterol $^{\mathrm{c}}$ & $131 \pm 5$ & $298 \pm 6$ & $\mathrm{P}<0.001$ \\
\hline Triglyceride $^{c}$ & $146 \pm 4$ & $430 \pm 10$ & $\mathrm{P}<0.001$ \\
\hline LDL-C $C^{c}$ & $68 \pm 3$ & $154 \pm 5$ & $\mathrm{P}<0.001$ \\
\hline HDL-C ${ }^{c}$ & $45.4 \pm 0.8$ & $35.7 \pm 0.8$ & $\mathrm{P}<0.001$ \\
\hline ApoAI $^{c}$ & $138 \pm 2$ & $119 \pm 2$ & $\mathrm{P}<0.001$ \\
\hline $\operatorname{ApoB}^{c}$ & $48 \pm 1.2$ & $114 \pm 3$ & $\mathrm{P}<0.001$ \\
\hline АроB/ароAI & $0.70 \pm 0.24$ & $1.44 \pm .039$ & $\mathrm{P}<0.001$ \\
\hline
\end{tabular}

The molecular characteristics of the observed genotypes of the (G-75A) and (C83T) apoAI alleles have been shown in Table 2. Figure 2 shows the electrophoretic pattern of apoAI gene PCR products ( $433 \mathrm{bp}$ ) digested by MspI in cases, along with the DNA size marker in different electrophoresis runs.

Table 2. Molecular Characteristics of Observed Genotypes of (G-75A ) and (+ 83) ApoAI Alleles

\begin{tabular}{|c|c|c|c|}
\hline Genotypes & Alleles & MspI Function & $\begin{array}{c}\text { Restriction } \\
\text { Fragments, bp }\end{array}$ \\
\hline GG/++ & $\begin{array}{c}-75 \text { Allele }(\mathrm{G} \\
\text { allele })+83 \text { allele } \\
(+ \text { allele })\end{array}$ & $\begin{array}{l}\text { The enzyme cut } \\
\text { both restriction } \\
\text { sites }\end{array}$ & $209,113,66,45$ \\
\hline GG/- - & $\begin{array}{c}-75 \text { Allele }(\mathrm{G} \\
\text { allele })+83 \text { allele } \\
\quad(- \text { allele })\end{array}$ & $\begin{array}{l}\text { The Absence of } \\
\text { restriction site at } \\
+83\end{array}$ & $254,113,6$ \\
\hline GG/+- & $\begin{array}{c}-75 \text { Allele }(\mathrm{G} \\
\text { allele })+83 \text { allele } \\
\quad(- \text { allele })^{\mathrm{a}}\end{array}$ & $\begin{array}{l}\text { The Absence of } \\
\text { restriction site at } \\
+83\end{array}$ & $254,209,113,66$ \\
\hline AA $/++$ & $\begin{array}{l}-75 \text { Allele (A } \\
\text { allele })+83 \text { allele } \\
\quad(+ \text { allele })\end{array}$ & $\begin{array}{l}\text { The Absence of } \\
\text { restriction site at } \\
-75\end{array}$ & $209,179,66,45$ \\
\hline GA/ $/++$ & $\begin{array}{c}-75 \text { Allele }(\mathrm{G} \\
\text { allele })^{\mathrm{b}}+83 \text { allele } \\
(- \text { allele })\end{array}$ & $\begin{array}{l}\text { The Absence of } \\
\text { restriction site at } \\
-75\end{array}$ & $209,179,113,66,45$ \\
\hline
\end{tabular}

\footnotetext{
a (+83) Allele observed as heterozygote
}

b $(-75)$ Allele observed as heterozygote
4.2. Linkage Disequilibrium and Association Between Analysis Allelic Frequency and Genotype Polymorphism for MspI (G-75A) and (C83T) Variants

Table 3 shows the allelic frequency and genotype distribution of (G-75A) polymorphic site in apoAI gene promoter. The most prevalent variant at the (G-75A) locus was GG. The allelic frequency at the (G-75A) loci was not significantly different in the hyperlipidemia and normal control groups $(\mathrm{P}=0.36)$. The minor allele $(\mathrm{A})$ frequencies of this polymorphism were 0.12 and 0.17 for the control and hyperlipidemic groups, respectively. The differences were not significant. The genotype distribution of the (G-75A) MspI sites were all in Hardy-Weinberg equilibrium (Table 4).

Table 3 shows the allelic frequency and genotype distribution of MspI (C83T) polymorphic site in apoAI gene first intron. The genotype distribution of (C83T) MspI sites was all in Hardy-Weinberg equilibrium (Table 4). A significant difference in frequency between 3 genotypes of MspI (C83T) polymorphism $(\mathrm{P}=0.026)$ was found. The variant of ++ (CC) at (C83T) locus was the most prevalent, so that the percentage in the hyperlipidemic and normal control were $80.3 \%$ and $95 \%$, respectively (Table 3). In the hyperlipidemic group (+-), the variant frequency has shown a significant increase in comparison to the control group $(\mathrm{P}<0.05)$. The minor allele frequencies were 0.105 and 0.03 in the hyperlipidemic and control groups, respectively, and when analyzed, a statistically difference was found $(\mathrm{P}=0.006)$.

\subsection{Effect of MspI (G-75A) and (C83T) Genotypes on Serum Lipid Profile and Apo Proteins}

Individuals with the GG and GA genotypes had high total cholesterol in comparison with those with the AA genotype. The serum levels of lipid and lipoprotein for all genotypes of the MspI (G-75A) apoAI gene were not significantly different. The odd ratio for hyperlipidemia among individuals with the GA genotype compared to that for those with the AA genotype was 0.667 (95\% CI: $0.039-11.446, \mathrm{P}=0.78$ ). The odd ratio for hyperlipidemia among individuals with the GG genotype in comparison to that for those with the AA genotype was 1.137 (95\% CI: $0.069-18.650, \mathrm{P}=0.928$ ).

Significant differences were observed in the serum levels of HDL-c and apoAI between different genotypes of MspI (C83T) $(\mathrm{P}<0.001$ and $\mathrm{P}<0.02$, respectively $)$ in the hyperlipidemic group when the concentrations of HDL-c and apoAI in the minor allele (-) were less than those for the (++) genotype. For the normal control group, our results did not show any significant differences among all genotypes of MspI (C83T). The odd ratio for hyperlipidemia in individuals with the (+-) genotype in comparison to that for individuals with the (++) genotype was 0.26 (95\% CI: $0.81-0.833$, $\mathrm{P}=0.023)$. The odd ratio for hyperlipidemia in individuals 


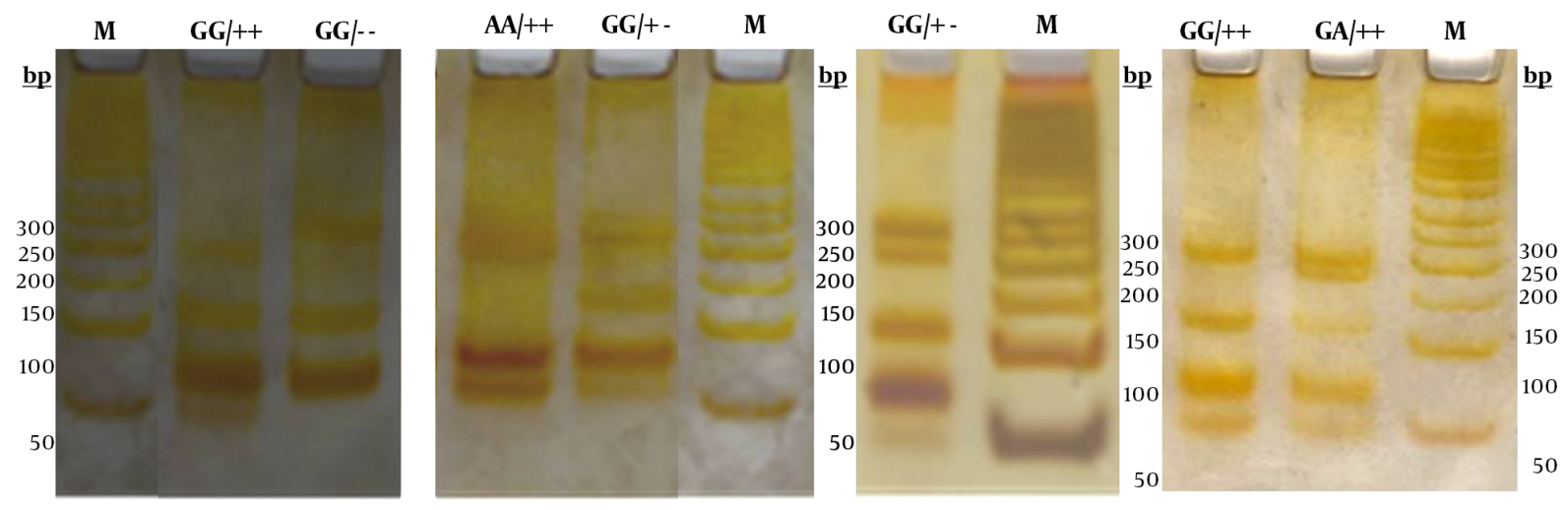

$\mathrm{M}$ is 50 base pairs (bp) DNA size marker. The three (G-75A) genotypes are GG, AG, AA and the three genotypes for (C83T) were shown as (++), (+-), and (-). The Msp1 digested fragments for different genotypes were as the following: GG/++ (45, 66, 113, and 209), GG/-(66, 113, 254), AA/++ (45, 66, 179, and 209), GG/+- (66, 113, 209, 254), GA/++ (45, 66, 113, 179, and 209).

Table 3. Genotype and Allele Frequencies of ApoAI Gene Polymorphisms (G-75A) and (C83T) Among Hyperlipidemic Cases and Normolipidemic Controls

\begin{tabular}{|c|c|c|c|c|c|}
\hline Polymorphic Site & Groups & Genotypes & $\mathbf{N}(\%)$ & Allelic Frequency & $\mathbf{P}$ \\
\hline \multirow{4}{*}{ (G-75A) locus } & \multirow{4}{*}{ Hyperlipidemic } & GG & $51(67)$ & $(G)=0.83$ & \multirow{5}{*}{0.36} \\
\hline & & GA & $24(32)$ & $(A)=0.17$ & \\
\hline & & AA & $1(1.3)$ & & \\
\hline & & Total & 76 & & \\
\hline \multirow{12}{*}{ (C83T) locus } & \multirow{4}{*}{ Control } & GG & $58(77.3)$ & $(G)=0.88$ & \\
\hline & & GA & $16(21.3)$ & $(A)=0.12$ & \multirow{8}{*}{$<0.05$} \\
\hline & & AA & $1(1.3)$ & & \\
\hline & & Total & 75 & & \\
\hline & \multirow{4}{*}{ Hyperlipidemic } & ++ & $61(80.3)$ & $(+)=0.895$ & \\
\hline & & +- & $14(18.4)$ & $(-)=0.105$ & \\
\hline & & $-\cdot$ & $1(1.3)$ & & \\
\hline & & Total & 76 & & \\
\hline & \multirow{4}{*}{ Control } & ++ & $71(95)$ & $(+)=0.97$ & \\
\hline & & +- & $4(5)$ & $(-)=0.03$ & \\
\hline & & -- & 0 & & \\
\hline & & Total & 75 & & \\
\hline
\end{tabular}

with the (-) genotype in comparison to that for individuals with the (++) genotype was 3.642 (95\% CI: $0.396-33.484, \mathrm{P}=$ $0.254)$.

\subsection{Haplotypes Frequency and ApoB/ApoAI Ratio}

We observed 5 combinations of the two polymorphisms in this study: GG/++, GG/--, GG/+-, AA/ ++, and GA/+ + (Figure 2 and Table 2). Table 5 shows the combined genotype distribution. The haplotype frequencies were statis- tically different between the hyperlipidemic and control groups of the studied population $(\mathrm{P}=0.018)$. Overall, in the normal control population, GG/++ or GG/CC double homozygote variant was the most prevalent (72\%). In the hyperlipidemic group, the frequency of GG/++, GA/++, and GG/+- haplotypes were $47 \%, 36.6 \%$, and $14 \%$ respectively. The least prevalent haplotypes in both groups were GG/- and $\mathrm{AA} /++$.

The ApoB/ApoAI ratio in GG/++ $(\mathrm{n}=90), \mathrm{GG} /+-(\mathrm{n}=$ 
Table 4. Distribution of Observed and Expected Number of Haplotypes and Frequency for (-75) and (C83T)

\begin{tabular}{|c|c|c|c|c|}
\hline Locus & Haplotype & Observed & Expected & Frequency \\
\hline \multicolumn{5}{|c|}{ (-75) locus } \\
\hline & GG & 109 & 110.2 & $(G)=0.854$ \\
\hline & GA & 40 & 37.6 & $(A)=0.146$ \\
\hline & AA & 2 & 3.2 & \\
\hline & Heterozygosity & & & 0.26 \\
\hline \multicolumn{5}{|c|}{ (C83T) locus } \\
\hline & ++ & 132 & 131.7 & $(+)=0.0662$ \\
\hline & + & 18 & 18.66 & $(-)=0.933$ \\
\hline & - & 1 & 0.66 & \\
\hline & Heterozygosity & & & 0.26 \\
\hline
\end{tabular}

Table 5. Combined Genotypes Distribution for MspI Polymorphisms

\begin{tabular}{lccc}
\hline Genotypes & Hyperlipidemia (\%) & Control (\%) & P \\
\hline GG++ & $36(47.36)$ & $54(72)$ & \\
\hline GG+- & $14(18.4)$ & $4(5.34)$ & $\mathbf{0 . 0 1 8}$ \\
\hline GG- & $1(1.32)$ & 0 & \\
\hline GA++ & $24(31.6)$ & $16(21.33)$ & \\
\hline AA++ & $1(1.32)$ & $1(1.33)$ & \\
\hline
\end{tabular}

$18)$, and GG/- $(\mathrm{n}=1)$ haplotypes showed an ascending trend $(1.02 \pm 0.05,1.29 \pm 0.07$ and 1.9 , respectively). The apoB/apoAI ratio in $\mathrm{AA} /++$ was lower than $\mathrm{GA} /++$ haplotype $(0.71 \pm 0.03$ VS. $1.1 \pm 0.08)$.

\section{Discussion}

The main finding of this study was that the frequency and relevant haplotype in the (G-75A) and (C83T) genotypes of the apoAI gene in hyperlipidemic and normal individuals are different. The most abundant alleles in the (G75A) and (C83T) genotypes of the apoAI gene were GG and $(++)$, respectively. We found that for the (C83T) genotype, but not (G-75A), the hyperlipidemic and control groups are significantly different in allelic frequencies, minor alleles, and levels of apoAI and LDL-C in plasma. However, when evaluating the combination polymorphism of these two genotypes in the studied population, the most abundant haplotype in the control group was GG/++, whereas in the hyperlipidemic group, the frequency of this haplotype decreased and the percentages of the GA/++ and $\mathrm{GG} /+-$ haplotypes increased. In addition, the study of the apoB100/apoAI ratio showed that A and - alleles at these polymorphic sites have a protective effect against hyperlipidemia in the studied population.

The allelic frequency at (G-75A) locus of the apoAI gene was 0.855 for the rare allele A, and 0.145 for the $G$ allele. In the case of the (C83T) polymorphic site, the allelic frequency was 0.9325 and 0.0675 for (+) and (-) alleles, respectively. In our study, the allelic frequency was different in hyperlipidemic and control groups (Table 6). The previous studies of the apoAI polymorphism of these two loci were conducted in healthy individuals $(13-15,26,30,31)$. In our study, the allelic frequency results were similar to the previous studies in Iran (14), India (13, 32), Kuwait, Japan (33), North America (31), and Africa (30), in the control and hyperlipidemic group. Unlike(G-75A) locus, in the case of rare alleles (-) of (C83T) variant, the hyperlipidemia allelic frequency was very different in comparison to other results.

In contrast to the studies by Bora et al. (13), Kamboh et al. (15), Dawar et al., and Biswas et al. (19, 34), the homozygous TT (-) genotype was observed in our study. The genotype has been observed only in a few studies, such as those by Sigurdsson et al. and Heng et al. $(35,36)$, and accounts for less than 1 percent of the population. We also observed one TT genotype in the hyperlipidemic group.

It seems that the cause for the same allelic frequencies in our control subjects and those in the study by Daneshpour et al. (14) is the ancestral homology of the Iranian community and also, partially, the geographical proximity to Tehran. The ethnicity of Semnani has no effect on the results of the allele frequency in the Iranian population. The difference in allelic frequency seen in the hyperlipidemic group in our study and other studies may be because some genotypes increase the ability of individuals to increase their lipoprotein levels.

In our study, as reported by Dallinga-Thie et al. (37), 
Table 6. Allelic Frequency Comparison

\begin{tabular}{|c|c|c|c|c|}
\hline \multirow{2}{*}{ References - Country } & \multicolumn{2}{|c|}{ (C83T) Allelic Frequency } & \multicolumn{2}{|c|}{ (G-75A) Allelic Frequency } \\
\hline & G Allele & A Allele & + Allele & - Allele \\
\hline Current study, hyperlipidemic group & 0.83 & 0.17 & 0.895 & 0.105 \\
\hline Current study, Control group & 0.88 & 0.12 & 0.978 & 0.03 \\
\hline Daneshpour et al. 2012-Iran (14) & 0.862 & 0.138 & 0.946 & 0.054 \\
\hline Al-Bustan et al. 2013- Kuwait (26) & 0.807 & 0.193 & 0.964 & 0.036 \\
\hline Bai et al. 1996- Japan (33) & 0.865 & 0.135 & - & - \\
\hline Larson et al. 2002-North America (31) & 0.845 & 0.155 & 0.955 & 0.045 \\
\hline Kamboh et al. 1996-North America (30) & 0.817 & 0.183 & 0.967 & 0.033 \\
\hline Kamboh et al. 1999-African, Nigeria (15) & 0.899 & 0.101 & 0.598 & 0.402 \\
\hline Bora et al. 2016-northeast India (13) & 0.78 & 0.22 & 0.94 & 0.06 \\
\hline
\end{tabular}

Heng et al. (35), and Bora et al. (13), the A allele had no effect on the concentration of apoAI protein in the blood. Of course, in our study, the concentration of lipids in the GG genotype was slightly higher than that for the other genotypes, but no significant difference was observed. The results of our study in this regard were not consistent with the results of other studies (19,30,36, 38-40).

In our study, a significant association was found between the (C83T) apoAI gene SNP and apoAI protein in the blood in the hyperlipidemic group, which is similar to the results of the studies by Kamboh et al. (15), Dawar et al. (20), and Larson et al. (31), whereas other studies by Heng et al. (35) de Franca et al. (41), Jia et al. (42), Padmaja et al. (43), and Chen et al. (17) did not show any association.

\subsection{Conclusion}

Our study on (G-75A) locus mutations is consistent with most previous studies, but concerning (C83T), the results are different in the hyperlipidemic group. In the hyperlipidemic group, the allele frequency of the genotypes, the concentration of apoAI, and the apoB100/apoA-I ratio were significantly different. On the other hand, when the haplotypes of these two genotypes were also examined, it was determined that the (G-75A) locus could also be impressive. Therefore, using a larger hyperlipidemic sample size to study the effect of these mutations in later studies is recommended. In addition to examining the effects of genotypes, haplotypes should also be investigated.

\section{Acknowledgments}

This study was supported by grants from Semnan University of Medical Sciences, Semnan, Iran.

\section{References}

1. Nelson RH. Hyperlipidemia as a risk factor for cardiovascular disease. Prim Care. 2013;40(1):195-211. doi: 10.1016/j.pop.2012.11.003. [PubMed: 23402469].

2. Agnoli C, Grioni S, Sieri S, Sacerdote C, Vineis P, Tumino R, et al. Colorectal cancer risk and dyslipidemia: a case-cohort study nested in an Italian multicentre cohort. Cancer Epidemiol.2014;38(2):144-51. doi: 10.1016/j.canep.2014.02.002. [PubMed: 24636241].

3. Yao X, Tian Z. Dyslipidemia and colorectal cancer risk: a meta-analysis of prospective studies. Cancer Causes Control. 2015;26(2):257-68. doi: 10.1007/s10552-014-0507-y. [PubMed: 25488827].

4. Katsiki N, Mikhailidis DP, Mantzoros CS. Non-alcoholic fatty liver disease and dyslipidemia: An update. Metabolism. 2016;65(8):1109-23. doi: 10.1016/j.metabol.2016.05.003. [PubMed: 27237577].

5. Cole CB, Nikpay M, McPherson R. Gene-environment interaction in dyslipidemia. Curr Opin Lipidol. 2015;26(2):133-8. doi: 10.1097/MOL.0000000000000160. [PubMed: 25692343].

6. Ebrahimi H, Emamian MH, Hashemi H, Fotouhi A. Dyslipidemia and its risk factors among urban middle-aged Iranians: A population-based study. Diabetes Metab Syndr. 2016;10(3):149-56. doi: 10.1016/j.dsx.2016.01.009. [PubMed: 27033172].

7. Tabatabaei-Malazy O, Qorbani M, Samavat T, Sharifi F, Larijani B, Fakhrzadeh $\mathrm{H}$. Prevalence of dyslipidemia in iran: a systematic review and meta-analysis study. Int J Prev Med. 2014;5(4):373-93. [PubMed: 24829725].

8. Bandegi AR, Firoozrai M, Ehsani Zonouz A, Akbari Eidgahi MR, Shabani AA, Malek M. Study of XmnI polymorphism in $5^{-}$region of the apoAI gene in Iranian hyperlipidemic subjects. Koomesh J. 2004;6(1):63-70.

9. Bandegi AR, Firoozrai M, Akbari Eidgahi MR, Kokhaei P. SstI Polymorphism of the Apolipoprotein CIII Gene in Iranian Hyperlipidemic Patients: A Study in Semnan Province. Iran J Basic Med Sci. 2011;14(6):50613. [PubMed: 23493241].

10. Bandegi AR, Firoozray M, Akbari-Eydgahi MR. Association between Lipoprotein Lipase Hind III Polymorphism and Serum Levels of Lipids in Semnan City.J Kerman Univ Med Sci. 2012;19(3):233-42.

11. Walldius G, Jungner I. Rationale for using apolipoprotein B and apolipoprotein A-I as indicators of cardiac risk and as targets for lipid-lowering therapy. Eur Heart J. 2005;26(3):210-2. doi: 10.1093/eurheartj/ehio77. [PubMed: 15618031].

12. Dong H, Chen W, Wang X, Pi F, Wu Y, Pang S, et al. Apolipoprotein A1, B levels, and their ratio and the risk of a first stroke: a metaanalysis and case-control study. Metab Brain Dis. 2015;30(6):1319-30. doi: 10.1007/s11011-015-9732-7. [PubMed: 26363640]. 
13. Bora K, Pathak MS, Borah P, Hussain MI, Das D. Single nucleotide polymorphisms of APOA1 gene and their relationship with serum apolipoprotein A-I concentrations in the native population of Assam. Meta Gene. 2016;7:20-7. doi: 10.1016/j.mgene.2015.10.005. [PubMed: 26702398].

14. Daneshpour MS, Faam B, Mansournia MA, Hedayati M, Halalkhor S, Mesbah-Namin SA, et al. Haplotype analysis of Apo AI-CIII-AIV gene cluster and lipids level: Tehran Lipid and Glucose Study. Endocrine. 2012;41(1):103-10. doi: 10.1007/s12020-011-9526-6. [PubMed: 22105741].

15. Kamboh MI, Aston CE, Nestlerode CM, McAllister AE, Hamman RF. Haplotype analysis of two APOA1/MspI polymorphisms in relation to plasma levels of apo AI and HDL-cholesterol. Atheroscler. 1996;127(2):255-62.

16. Feng DW, Ma RL, Guo H, He J, Yan YZ, et al.Muratbek. Association of APOA1 gene polymorphisms (rs670, rs5069, and rs2070665) with dyslipidemia in the Kazakhs of Xinjiang. Genet Mol Res. 2016;15(2). doi: 10.4238/gmr.15028094. [PubMed: 27173266].

17. Chen ES, Mazzotti DR, Furuya TK, Cendoroglo MS, Ramos LR, Araujo LQ, et al. Apolipoprotein A1 gene polymorphisms as risk factors for hypertension and obesity. Clin Exp Med. 2009;9(4):319-25. doi: 10.1007/s10238-009-0051-3. [PubMed: 19408098].

18. Toptas B, Gormus U, Ergen A, Gurkan H, Kelesoglu F, Darendeliler F, et al. Comparison of lipid profiles with APOA1 MspI polymorphism in obese children with hyperlipidemia. In Vivo. 2011;25(3):425-30. [PubMed: 21576418].

19. Dawar R, Gurtoo A, Singh R. Apolipoprotein A1 Gene Polymorphism (G-75a and C+83t) in Myocardial Infarction-a Pilot Study in the North Indian Population. Atheroscler. 2009;207(1):E12-E3.

20. Dawar R, Gurtoo A, Singh R. Apolipoprotein A1 gene polymorphism (G-75A and $\mathrm{C}+83 \mathrm{~T}$ ) in patients with myocardial infarction: a pilot study in a north Indian population. Am J Clin Pathol. 2010;134(2):24955. doi: 10.1309/AJCPKPTXQ3QN1IFG. [PubMed: 20660328].

21. Ding Y, Zhu MA, Wang ZX, Zhu J, Feng JB, Li DS. Associations of polymorphisms in the apolipoprotein APOA1-C3-A5 gene cluster with acute coronary syndrome. J Biomed Biotechnol. 2012;2012:509420. doi: 10.1155/2012/509420. [PubMed: 22675253].

22. Pulkkinen A, Viitanen L, Kareinen A, Lehto S, Laakso M. MspI polymorphism at +83 bp in intron 1 of the human apolipoprotein A1 gene is associated with elevated levels of HDL cholesterol and apolipoprotein A1 in nondiabetic subjects but not in type 2 diabetic patients with coronary heart disease. Diabetes Care. 2000;23(6):791-5. [PubMed: 10840998].

23. Morcillo S, Cardona F, Rojo-Martinez G, Esteva I, De Adana MSR, Tinahones F. Association between MspI polymorphism of the Apo AI gene and type 2 diabetes mellitus. Diabet. 2004;53:A541-A.

24. Wu Y, YuY,Zhao T, Wang S, Fu Y, Qi Y, et al. Interactions of Environmental Factors and APOA1-APOC3-APOA4-APOA5 Gene Cluster Gene Polymorphisms with Metabolic Syndrome. PLoS One. 2016;11(1). e0147946. doi: 10.1371/journal.pone.0147946. [PubMed: 26824674].

25. Sorkin SC, Forestiero FJ, Hirata MH, Guzman EC, Cavalli SA, Bertolami MC, et al. APOA1 polymorphisms are associated with variations in serum triglyceride concentrations in hypercholesterolemic individuals. Clin Chem Lab Med. 2005;43(12):1339-45. doi: 10.1515/CCLM.2005.229. [PubMed: 16309370].

26. Al-Bustan SA, Al-Serri AE, Annice BG, Alnaqeeb MA, Ebrahim GA. Resequencing of the APOAI promoter region and the genetic association of the $-75 \mathrm{G}>\mathrm{A}$ polymorphism with increased cholesterol and low density lipoprotein levels among a sample of the Kuwaiti population. BMC Med Genet. 2013;14:90. doi: 10.1186/1471-2350-14-90. [PubMed: 24028463].

27. Bandarian F, Hedayati M, Daneshpour MS, Naseri M, Azizi F. Genetic polymorphisms in the APOA1 gene and their relationship with serum HDL cholesterol levels. Lipids. 2013;48(12):1207-16. doi: 10.1007/s11745013-3847-6. [PubMed: 24081495].

28. Pakdel A, Akbari eydgahi MR, Bandegi AR. Lack of association between PstI polymorphism in the 3' flanking region of the apolipoprotein
AI gene and serum lipids levels in an Iranian population. Koomesh J. 2017;19(3):619-25.

29. Sakri FH, Mokhsin NAM, Ahmad WNHW, Rahman TA, Hoh BP, Nawawi HM. Genetic Association of Single Nucleotide Polymorphisms of Abca1, Apoa1 and Lcat Genes in Subjects with Low Concentration of High Density Lipoprotein-Cholesterol. Atheroscl. 2015;241(1):E109-E.

30. Kamboh MI, Bunker CH, Aston CE, Nestlerode CS, McAllister AE, Ukoli FA. Genetic association of five apolipoprotein polymorphisms with serum lipoprotein-lipid levels in African blacks. Genetic Epidemiol. 1999;16(2):205-22.

31. Larson IA, Ordovas JM, Barnard JR, Hoffmann MM, Feussner G, LamonFava S, et al. Effects of apolipoprotein A-I genetic variations on plasma apolipoprotein, serum lipoprotein and glucose levels. Clin Genet. 2002;61(3):176-84. [PubMed: 12000358].

32. Shanker J, Perumal G, Rao VS, Khadrinarasimhiah NB, John S, Hebbagodi S, et al. Genetic studies on the APOA1-C3-A5 gene cluster in Asian Indians with premature coronary artery disease. Lipids Health Dis. 2008;7:33. doi:10.1186/1476-511X-7-33. [PubMed:18801202].

33. Bai H, Saku K, Liu R, Jimi S, Arakawa K. Analysis of a new polymorphism in the human apolipoprotein A-I gene: association with serum lipoprotein levels and coronary heart disease. J Cardiol. 1996;28(4):207-12. [PubMed: 8934336].

34. Biswas S, Ghoshal PK, Halder B, Ganguly K, DasBiswas A, Mandal $\mathrm{N}$. Apolipoproteins $\mathrm{AI} / \mathrm{B} / \mathrm{E}$ gene polymorphism and their plasma levels in patients with coronary artery disease in a tertiary carecenter of Eastern India. Indian Heart J. 2013;65(6):658-65. doi: 10.1016/j.ihj.2013.10.003. [PubMed: 24407534].

35. Heng CK, Low PS, Saha N. Variations in the promoter region of the apolipoprotein A-1 gene influence plasma lipoprotein(a) levels in Asian Indian neonates from Singapore. Pediatr Res. 2001;49(4):514-8. doi: 10.1203/00006450-200104000-00013. [PubMed: 11264435].

36. Sigurdsson G, Gudnason V, Humphries SE. Interaction between a polymorphism of the apo AI promoter region and smoking determines plasma levels of HDL and apo AI. Arterioscl Thrombos Vascul Biol. 1992;12(9):1017-22.

37. Dallinga-Thie GM, Bu XD, van Linde-Sibenius Trip M, Rotter JI, Lusis AJ, de Bruin TW. Apolipoprotein A-I/C-III/A-IV gene cluster in familial combined hyperlipidemia: effects on LDL-cholesterol and apolipoproteins B and C-III. J Lipid Res. 1996;37(1):136-47. [PubMed: 8820109].

38. Jeenah M, Kessling A, Miller N, Humphries S. G to A substitution in the promoter region of the apolipoprotein AI gene is associated with elevated serum apolipoprotein AI and high density lipoprotein cholesterol concentrations. Mol Biol Med. 1990;7(3):233-41. [PubMed: 1977072].

39. Rai TS, Khullar M, Sehrawat BS, Ahuja M, Sharma PK, Vijayvergiya R, et al. Synergistic effect between apolipoprotein E and apolipoprotein A1 gene polymorphisms in the risk for coronary artery disease. Mol Cell Biochem. 2008;313(1-2):139-46. doi: 10.1007/s11010-008-9751-3. [PubMed: 18398670].

40. Talmud PJ, Ye S, Humphries SE. Polymorphism in the promoter region of the apolipoprotein AI gene associated with differences in apolipoprotein AI levels: the European Atherosclerosis Research Study. Genet Epidemiol. 1994;11(3):265-80. doi: 10.1002/gepi.1370110305. [PubMed: 8088507].

41. de Franca E, Alves JG, Hutz MH. APOA1/C3/A4 gene cluster variability and lipid levels in Brazilian children. Brazilian J Med Biologic Res. 2005;38(4):535-41.

42. Jia L, Bai H, Fu M, Xu Y, Yang Y, Long S. Relationship between plasma HDL subclasses distribution and apoA-I gene polymorphisms. Int J Clinic Chem. 2005;360(1-2):37-45.

43. Padmaja N, Kumar MR, Adithan C. Association of polymorphisms in apolipoprotein A1 and apolipoprotein B genes with lipid profile in Tamilian population. Indian Heart J. 2009;61(1):51-4. [PubMed: 19729689]. 